\title{
Determination of role of gluten prepared bread against hypercholesterolemic rats
}

\author{
Muhammad Hanif Mughal* \\ Homeopathic Clinic, Islamabad, Pakistan
}

\begin{abstract}
The current study was used to determine the significant role of gluten-based bread to curtail the hypercholesterolemia discrepancies in experimental subjects. For this purpose, two different wheat varieties including Lasani-08 and AARI-11 have been procured and further used to prepare the gluten-based bread by using different concentrations of gluten protein. The mean values for body weight for T0, T1, T2, and T3 treatments in study II and study III were reported as $361.54 \pm 20.62 \&$ $407.53 \pm 17.82,372.44 \pm 25.83 \& 464.44 \pm 20.83,364.22 \pm 18.96 \& 418.66 \pm 27.42$, and $371.84 \pm 25.63 \& 420.19 \pm 13.89$ for T0, T1, T2, and T3 treatments, accordingly. The rats were supplemented with the dose of bread with modified gluten $15 \%$ (T3) showed higher reduction in cholesterol as $79.42 \pm 4.11$ \& $78.13 \pm 2.01 \mathrm{mg} / \mathrm{dL}$ followed by $81.24 \pm 4.05 \& 81.84 \pm 2.94 \mathrm{mg} / \mathrm{dL}$ (T2=Modified gluten bread T1\%10 Gluten), and 82.41 $\pm 4.56 \& 82.82 \pm 4.53 \mathrm{mg} / \mathrm{dL}$ (T1=Modified gluten bread T1\%5 Gluten) as compared to $84.88 \pm 2.36$ (T0), respectively. Similarly, mean values for low density lipoprotein were reduced from T0 (82.65 $\pm 3.36 \mathrm{mg} / \mathrm{dl})$ to $30.65 \pm 1.40,30.38 \pm 1.45$, and T3 $(78.63 \pm 3.21 \mathrm{mg} / \mathrm{dL})$.
\end{abstract}

\section{Introduction}

Cereals have been known to meet human needs as the most essential staple foods. Among these cereal crops, by supplying numerous types of food-based products, wheat feeds more than one third of the world's population. They are also prominent and significant source of carbohydrates, proteins, and calories as well as has been cultivated on maximum area as compared to other cereal crops [1]. Wheat is a potential source of macro and micro nutrients such as carbohydrates (78.10\%), fat $(2.10 \%)$, proteins $(14.70 \%)$, minerals $(2.10 \%)$, and significant vitamin (thiamine and vitamin-B). Multiple factors such as temperature, weather, soil and genetic variation significantly affect the wheat nutritional composition [2]. Wheat is also used for multiple purposes, including bread and biscuits preparation, wheat beer brewing, ethanol production, clothing products, and animal feed [3]. Gluten in wheat is the primary protein made up of glutenins and gliadins. After mixing wheat flour with water, dough is formed which further forms a continuous network. This network has the cohesiveness and viscoelastic properties used in the preparation of different products like noodles, breads and other foods. The quality of gluten protein constitutes approximately $80 \%$ of the total wheat protein which is 7 to $22 \%[4,5]$. Generally, diabetes mellitus is the most common condition and around 366 million people suffer from this disease, which is expected to reach 552 million by 2030. This disease is characterized by increased blood sugar production, insulin output and secretion deficits [6]. Those included are agricultural practices and breeding techniques to minimize micronutrient malnutrition. Wheat gluten triggers a significant increase in insulin production, a decrease in blood glucose levels, plasma cholesterol, inflammatory cytokines, cardiovascular risks, and triglycerides, as well as a decrease in systolic blood pressure, pulse pressure and body fat.

\section{Materials and methods}

\section{Raw materials}

Wheat varieties i.e. Lasani-08 and AARI-11 were used and $2 \mathrm{~kg}$ grains from each variety were tempered to obtain moisture level (15.5\%) by using the guidelines of AACC [7] method No. 26-95. Afterwards, a Brabender Quadrumate Senior Mill was milled the tempered wheat grains. By blending of two flour millstreams i.e. reduction roll flour and break roll flour, straight grade flour was prepared.

\section{Efficacy studies}

In vivo studies: A bio-efficacy trial was conducted to determine the role of bread prepared by different concentrations of gluten against different disorders such as hypercholesterolemia and hyperglycemia. For this purpose, forty male Sprague dawley rats were procured from National Institute of Health (NIH), Islamabad and housed under in the Animal Room of Imperial College of Business Studies, Lahore.

Basal diet has been given to rats for a period of one week to acclimatize. The environmental conditions as temperature $\left(23 \pm 2^{\circ} \mathrm{C}\right)$ and humidity $(55 \pm 5 \%)$ were maintained together with $12 \mathrm{hr}$ light dark period for the entire efficacy test. At the initiation of study, baseline developed by scarifying some rats. For this purpose, there were three studies were done such as control, hyperglycemia and hypercholesterolemia rats as

${ }^{\star}$ Correspondence to: Muhammad Hanif Mughal, Homeopathic Clinic, Islamabad, Pakistan, E-mail: drmhanifmughal@gmail.com

Key words: wheat, gluten-based bread, efficacy trial, lipid profile

Received: August 07, 2019; Accepted: September 11, 2019; Published: September 16, 2019 
mentioned in Table 1. Each study was comprised of 10 rats, divided in four equal groups, ten in each.

In study I, rats were fed on normal diet while streptozotocin (STZ) induction was fed on normal diet at a level of $65 \mathrm{mg} / \mathrm{kg}$ BW during study II. Nonetheless, rats identified as study III were given high cholesterol diet. In order to determine the therapeutic effect of gluten bread, control, gluten-based diet was subjected to the respective groups during 8 weeks of efficacy trials (Table 2). Physical parameters such as feed \& drink consumption and body weight were also determined during the efficacy trial. The rats were decapitated overnight and at the end of the study blood was collected in EDTA coated tubes. Hematological characteristics such as red \& white blood cell indices were initially tested for subsequent blood samples. Upon centrifugation, the serum separation was made from blood samples. The resulting serum was subjected by Microlab 300 (Merck, Germany) to measure various biochemical parameters such as total cholesterol, HDL, LDL, triglycerides, glucose and insulin levels. Furthermore, gluten bread therapeutic effects, resulting sample further tested liver and kidney test soundness.

Studies details are herein;

Study I: Normal rats: In the current study, 54 experimental rats are classified into four homogeneous groups fed on normal diet with simultaneous supply of various gluten bread concentrations. The basal diet (Appendix II) consisted of maize starch (66\%), cellulose (10\%), protein $(10 \%)$, maize oil $(10 \%)$, mineral $(3 \%)$ and vitamin mixture (1\%), respectively. In two other studies, the following methodology was performed to investigate the effect of altered gluten bread in separate rodent modeling against respective disorders i.e. hypercholesterolemia and hyperglycemia (Table 3).

Study II: Diabetic rats: A single intraperitoneal streptozotocin (STZ) injection@ $65 \mathrm{mg} / \mathrm{kg}$ was prepared in the citrate buffer $\mathrm{pH} 4.5$ for

Table 1. Different studies conducted in efficacy trial

\begin{tabular}{|c|c|}
\hline Study I & Normal rats \\
\hline Study II & Diabetic rats \\
\hline Study III & Hypercholesterolemic rats \\
\hline
\end{tabular}

Table 2. Diets and gluten based bread

\begin{tabular}{|c|c|c|c|c|c|c|c|c|c|c|c|c|}
\hline \multirow{3}{*}{$\begin{array}{l}\text { Studies } \\
\text { Groups }\end{array}$} & \multicolumn{4}{|c|}{ Study I } & \multicolumn{4}{|c|}{ Study II } & \multicolumn{4}{|c|}{ Study III } \\
\hline & \multicolumn{4}{|c|}{ Normal rats } & \multicolumn{4}{|c|}{ Diabetic rats } & \multicolumn{4}{|c|}{$\begin{array}{c}\text { Hypercholesterolemic } \\
\text { rats }\end{array}$} \\
\hline & 1 & 2 & 3 & 4 & 1 & 2 & 3 & 4 & 1 & 2 & 3 & 4 \\
\hline $\begin{array}{c}\text { Gluten based } \\
\text { bread }\end{array}$ & $\mathrm{T}_{0}$ & $\mathrm{~T}_{1}$ & $\mathrm{~T}_{2}$ & $\mathrm{~T}_{3}$ & $\mathrm{~T}_{0}$ & $\mathrm{~T}_{1}$ & $\mathrm{~T}_{2}$ & $\mathrm{~T}_{3}$ & $\mathrm{~T}_{0}$ & $\mathrm{~T}_{1}$ & $\mathrm{~T}_{2}$ & $\mathrm{~T}_{3}$ \\
\hline
\end{tabular}

$\mathrm{T}_{0}$ : Control; $\mathrm{T}_{1}: 5 \%$ modified gluten bread; $\mathrm{T}_{2}: 10 \%$ modified gluten bread; $\mathrm{T} 3: 15 \%$ modified gluten bread

Table 3. Mean values for physical parameters

\begin{tabular}{|c|c|c|c|c|c|}
\hline \multirow{2}{*}{ Parameters } & \multicolumn{4}{|c|}{ Treatments } & \multirow{2}{*}{ F value } \\
\hline & T0 & T1 & $\mathbf{T 2}$ & T3 & \\
\hline \multicolumn{6}{|c|}{ Body weight (g) } \\
\hline Study I & $241.07 \pm 12.08$ & $247.74 \pm 10.63$ & $236.51 \pm 17.54$ & $246.16 \pm 10.89$ & \\
\hline Study II & $361.54 \pm 20.62$ & $372.44 \pm 25.83$ & $364.22 \pm 18.96$ & $371.84 \pm 25.63$ & \\
\hline Study III & $407.53 \pm 17.82$ & $464.44 \pm 20.83$ & $418.66 \pm 27.42$ & $420.19 \pm 13.89$ & \\
\hline \multicolumn{6}{|c|}{ Feed Intake (g/day) } \\
\hline Study I & $13.22 \pm 1.1 \mathrm{a}$ & $13.88 \pm 0.83$ & $15.08 \pm 1.25 \mathrm{a}$ & $14.82 \pm 0.84$ & \\
\hline Study II & $16.59 \pm 0.47 \mathrm{~b}$ & $16.84 \pm 1.02$ & $19.28 \pm 0.78 \mathrm{a}$ & $17.64 \pm 0.8 \mathrm{a}$ & \\
\hline Study III & $16.43 \pm 0.6 \mathrm{~b}$ & $16.87 \pm 0.7$ & $17.48 \pm 0.8 \mathrm{a}$ & $17.28 \pm 0.6$ & \\
\hline
\end{tabular}

T0: Control; T1: 5\% modified gluten bread; T2: 10\% modified gluten bread; T3: $15 \%$ modified gluten bread diabetes induction in the respective group. In order to find out their therapeutic function, diabetic rats were subsequently given different concentrations of prepared modified gluten bread alongside normal diet.

Study III: Hypercholestrolemic rats: In study II, diet contained $1.5 \%$ cholesterol and cholic acid $(0.5 \%)$ in order to enhance the lipid profile marker of hypercholesterolemia rats. The prepared gluten bread was simultaneously taken to the rats to test their effect on the groups.

\section{Physical parameters}

Feed and drink intakes: By excluding spilled diet from total diet, feed intake was calculated on a daily basis, whereas each rat's drinking intake was also determined on a daily basis through measuring differences in graduated bottles [8].

Body weight gain: The body weight gain of each rat was as measured on a weekly basis throughout the study to determine the inhibiting effects of gluten-based food.

\section{Serum separation}

Blood samples have been obtained in commercially available red capped tubes for serum separation. At room temperature, the respective samples are allowed to coagulate for $30 \mathrm{~min}$. After centrifugation, the coagulated component was extracted by Centrifuge Machine (Model: 800, China)@ 4000 rpm for 6 min.

Serum lipid profile: By excluding spilled diet from total diet, feed intake was calculated on a daily basis, whereas each rat's drinking intake was also determined on a daily basis through measuring differences in graduated bottles [8].

Serum cholesterol level was determined via CHOD-PAP method using the protocol of Kim et al. [9] whereas high density lipoprotein (HDL) was investigated by cholesterol precipitant method as mentioned by Alshatwi et al. Low density lipoproteins (LDL) are analyzed in the resulting samples using the Kim et al. [9] process. Likewise, ttriglycerides level was determined by liquid triglycerides (GPO-PAP) method [9].

\section{Statistical analysis}

The data obtained for each parameter were analyzed using a completely randomized model using the Co-Stat-2003 Statistical Package (Cohort $\mathrm{v}-6.1)$ and the variance analysis was applied to assess the significance level [10].

\section{Results and discussions}

The mean values (Table 3) for body weight for T0, T1, T2, and T3 treatments in study I were observed as $241.07 \pm 12.08,247.74 \pm 10.63$, $236.51 \pm 17.54$, and $246.16 \pm 10.89$ g, respectively whereas values for study II and study III were reported as $361.54 \pm 20.62 \& 407.53 \pm 17.82$, $372.44 \pm 25.83 \& 464.44 \pm 20.83,364.22 \pm 18.96 \& 418.66 \pm 27.42$, and $371.84 \pm 25.63 \& 420.19 \pm 13.89$ for $\mathrm{T} 0, \mathrm{~T} 1, \mathrm{~T} 2$, and $\mathrm{T} 3$ treatments, accordingly. Regarding values of feed intake (g/day) for T0, T1, T2, and $\mathrm{T} 3$ in study I were recorded as $13.22 \pm 1.1,13.88 \pm 0.83,15.08 \pm 1.25$, and $14.82 \pm 0.84 \mathrm{~g} /$ day, respectively whilst mean values for T2 $(19.28 \pm 0.78$ g/day) followed by T0 ( $16.59 \pm 0.47 \mathrm{~g} /$ day), T2 (16.84 $\pm 1.02 \mathrm{~g} /$ day), and T3 (17.64 $\pm 0.8 \mathrm{~g} /$ day), accordingly. Furthermore, $16.43 \pm 0.6,16.87 \pm 0.7$, $16.87 \pm 0.7$, and $17.48 \pm 0.8 \mathrm{~g} /$ day values were explicated in $\mathrm{T} 0, \mathrm{~T} 1, \mathrm{~T} 2$, and $\mathrm{T} 3$, treatments, respectively (Table 3 ).

The administration of various doses of altered bread from wheat gluten displayed a non-significant impact on rat physical parameters. 
Due to various variables such as energy equilibrium, these diets had no impact on body weight and feed consumption in rats fed starchbased diets; a marked rise in nutritional fiber consumption [11].

Vuksun et al. found that the supplemented diet of wheat had a negative impact on body weight. In addition, wheat fibers have been more effective in body weight management [12].

The mean values for cholesterol of hyperchoelsterolemic rats were mentioned in Table 4. The rats were supplemented with the dose of bread with modified gluten $15 \%$ (T3) showed higher reduction in cholesterol as $79.42 \pm 4.11 \& 78.13 \pm 2.01 \mathrm{mg} / \mathrm{dL}$ followed by $81.24 \pm 4.05$ \& 81.84 $\pm 2.94 \mathrm{mg} / \mathrm{dL}$ (T2=Modified gluten bread T1\%10 Gluten), and $82.41 \pm 4.56 \& 82.82 \pm 4.53 \mathrm{mg} / \mathrm{dL}$ ( $\mathrm{T} 1=$ Modified gluten bread $\mathrm{T} 1 \% 5$ Gluten) as compared to $84.88 \pm 2.36 \& 84.47 \pm 2.56$ (T0), respectively. Similarly, mean values for low density lipoprotein were reduced from T0 $(82.65 \pm 3.36 \mathrm{mg} / \mathrm{dl})$ to $\mathrm{T} 1(30.65 \pm 1.40), \mathrm{T} 2(30.38 \pm 1.45)$, and T3 $(32.63 \pm 3.21 \mathrm{mg} / \mathrm{dL})$. Moreover, triglycerides level significantly decreased from control T0 $(64.61 \pm 4.01 \mathrm{mg} / \mathrm{dL})$ treatment to T1 $(61.41 \pm 2.82 \mathrm{mg} / \mathrm{dl}), \mathrm{T} 2(60.82 \pm 2.15 \mathrm{mg} / \mathrm{dL})$, and T3 $(59.47 \pm 2.79 \mathrm{mg} /$ $\mathrm{dL})$, respectively in hypercholesterolemic rats. Likewise, levels of highdensity lipoprotein significantly increased in T3, T2, and T1 treatments as compared to T0 as $38.23 \pm 1.03 \mathrm{mg} / \mathrm{dL}, 37.65 \pm 2.15 \mathrm{mg} / \mathrm{dL}$, and $37.42 \pm 1.52 \mathrm{mg} / \mathrm{dL}$ from $35.71 \pm 2.68 \mathrm{mg} / \mathrm{dL}$, respectively.

The present findings are in line with researchers ' research, determining that wheat-based diet showed significant reduction in complete serum cholesterol, low lipoprotein density and increased lipoprotein density owing to powerful antioxidant capacity and cellular structures being protected from peroxidation [13]. Similarly, different doses of wheat porridges at 20 and $30 \mathrm{~g} / 100$ grams significantly reduced cholesterol, low-density lipoprotein, triglycerides, and increased the level of high-density lipoprotein at the end of the study in hypercholesterolemic rats [14]. Similarly, in another study conducted by Jenkins and their colleagues, they found that wheat bran by using different concentrations ( 20 and $30 \mathrm{~g}$ in 100 $\mathrm{g}$ wheat flour) showed marked decreases in triglycerides, LDL, VLDL, and HDL improvement respectively. Wheat bran fibers also reduced cholesterol, LDL, and increased HDL concentrations by changing the amount of fatty acids in the short chain fatty acids [15].

Table 4. Lipid profile

\begin{tabular}{|c|c|c|c|c|c|}
\hline \multirow{2}{*}{ Parameters } & \multicolumn{5}{|c|}{ Treatments } \\
\hline & T0 & $\mathrm{T} 1$ & $\mathrm{~T} 2$ & $\mathrm{~T} 3$ & F value \\
\hline \multicolumn{6}{|l|}{ Cholesterol } \\
\hline Study I & $88.58 \pm 3.16$ & $87.98 \pm 2.06$ & $87.08 \pm 2.45$ & $86.36 \pm 1.06$ & $6.37^{\mathrm{NS}}$ \\
\hline Study II & $84.88 \pm 2.36 \mathrm{a}$ & $82.41 \pm 4.56 \mathrm{~b}$ & $81.24 \pm 4.05 \mathrm{c}$ & $79.42 \pm 4.11 \mathrm{~d}$ & $4.63^{*}$ \\
\hline Study III & $84.47 \pm 2.56 \mathrm{a}$ & $82.82 \pm 4.53 b$ & $81.84 \pm 2.94 \mathrm{c}$ & $78.13 \pm 2.01 \mathrm{~d}$ & $6.45^{*}$ \\
\hline \multicolumn{6}{|l|}{$\begin{array}{l}\text { Low density } \\
\text { lipoprotein }\end{array}$} \\
\hline Study I & $31.30 \pm 1.38$ & $30.26 \pm 1.74$ & $29.26 \pm 2.09$ & $30.86 \pm 3.19$ & $105.46^{\mathrm{NS}}$ \\
\hline Study II & $82.65 \pm 3.36 \mathrm{a}$ & $30.65 \pm 1.40 \mathrm{~b}$ & $30.38 \pm 1.45 c$ & $32.63 \pm 3.21 \mathrm{~b}$ & $96.49^{* *}$ \\
\hline Study III & $83.40 \pm 2.16 \mathrm{a}$ & $33.55 \pm 1.31 \mathrm{~b}$ & $31.48 \pm 1.62 \mathrm{c}$ & $30.71 \pm 2.91 \mathrm{~b}$ & $145.33 * *$ \\
\hline \multicolumn{6}{|l|}{ Triglycerides } \\
\hline Study I & $67.12 \pm 2.38$ & $65.21 \pm 2.38$ & $65.10 \pm 3.32$ & $63.24 \pm 1.78$ & $161.02^{\mathrm{NS}}$ \\
\hline Study II & $69.32 \pm 4.08 \mathrm{a}$ & $66.81 \pm 4.21 \mathrm{~b}$ & $65.51 \pm 2.72 \mathrm{c}$ & $63.67 \pm 2.79 b$ & $90.59 * *$ \\
\hline Study III & $71.22 \pm 3.38 \mathrm{a}$ & $67.81 \pm 4.01 \mathrm{~b}$ & $63.41 \pm 2.82 \mathrm{c}$ & $60.47 \pm 2.32 b$ & $134.23 * *$ \\
\hline \multicolumn{6}{|l|}{$\begin{array}{l}\text { High density } \\
\text { lipoprotein }\end{array}$} \\
\hline Study I & $33.23 \pm 3.15$ & $33.78 \pm 1.16$ & $34.07 \pm 3.64$ & $35.07 \pm 3.64$ & $11.17^{\mathrm{NS}}$ \\
\hline Study II & $35.71 \pm 2.68 \mathrm{a}$ & $37.42 \pm 1.52 \mathrm{a}$ & $37.65 \pm 2.15 b$ & $38.23 \pm 1.03 \mathrm{c}$ & $7.97 *$ \\
\hline Study III & $35.21 \pm 2.78 \mathrm{a}$ & $35.90 \pm 2.98 \mathrm{~b}$ & $36.24 \pm 2.87 \mathrm{a}$ & $37.14 \pm 2.54 \mathrm{c}$ & $5.63 *$ \\
\hline
\end{tabular}

Wheat bran administration at a pace of $5 \mathrm{~g} / \mathrm{kg}$ BW showed significantly reduced concentrations of LDL cholesterol, cholesterol, VLDL, as well as increased levels of HDL in patients with hyper cholesterol [16].

\section{Conclusion}

The current study was used to find out the therapeutic role of wheat based products to curtail the hypercholesterolemia and their linked complications. Wheat gluten is the natural protein found in wheat and used to prepare different food itnems for hypercholesteolemic patients. This gluten based bread has been found effectual to reduce the higher concentrations of cholesterol, triglycerides, low density lipoportein, and enhance the level of high density lipoportein. Modified gluten bread sales will increase as there are currently no wheat-based products for patients with celiac disease in Pakistan.

\section{References}

1. Shewry PR, Hey SJ (2015) The contribution of wheat to human diet and health. Food Energy Secur 4: 178-202. [Crossref]

2. Shewry PR, Halford NG (2002) Cereal seed storage proteins: structures, properties and role in grain utilization. J Exp Bot 53: 947-958.

3. Uauy C, Distelfeld A, Fahima T, Blechl A, Dubcovsky J (2006) A NAC Gene regulating senescence improves grain protein, zinc, and iron content in wheat. Science 314: 12981301.

4. Sapone A, Bai JC, Ciacci C, Dolinsek J, Green PH, et al. (2012) Spectrum of glutenrelated disorders: consensus on new nomenclature and classification. BMC Med 10: 13 .

5. Shewry PR, D'Ovidio R, Lafiandra D, Jenkins JA, Mills ENC, et al. (2009a) Wheat grain proteins Pp. 223-298 in Khan K, Shewry PR, eds. Wheat: chemistry and technology, 4th edn AACC, St Paul, MN, USA.

6. Tabatabaei-Malazya O, Larijania, B, Abdollahi, M (2013) A novel management of diabetes by meansof strong antioxidants' combination. Journal of Medical Hypotheses and Ideas 7: 25-30.

7. AACC (2000) Approved Methods of the AACC. 10th Edition, American Association of Cereal Chemists, St. Paul.

8. Wolf BW, Weisbrode SE (2003) Safety evaluation of an extract from Salacia oblonga. Food Chem Toxicol 41: 867-874. [Crossref]

9. Kim K, Kim H, Kwon J, Lee S, Kong H, et al. (2009) Hypoglycemic and hypolipidemic effects of processed Aloe vera gel in a mouse model of non-insulin-dependent diabetes mellitus. Phytomedicine 16: 856-863.

10. Steel RG, Torrie JH, Dickey DA (1997) Principles and procedures of statistics: A biological approach. McGraw-Hill.

11. Mercer LP, Gustafson JM, Higbee PT, Geno CE, SchweisthalMR, et al. (1984) Control of physiological responses in the rat bydietary nutrient concentration. $J$ Nutr 114: 144-152.

12. Scherf KA, Köhler P (2016) Wheat and gluten: technological and health aspects Ernahrungs Umschau 63: 166-175.

13. Wieser H, Bushuk W, MacRitchie F (2006) The polymeric glutenins. In: Wrigley C, Bekes F, Bushuk W (Hg). Gliadin and glutenin: the unique balance of wheat quality. American Association of Cereal Chemists International, St. Paul, MN, USA, pp: 213-240.

14. Bueno PCDS, Barbalho SM, Guiguer ÉL, Souza MDSS, Medeiros IRA, et al. (2019) Effects of green wheat (Triticum turgidum) and common wheat (Triticum aestivum) on the metabolic profile of wistar rats. J Med Food.

15. Jenkins DJ, Kendall CW, Vuksan V, Augustin LS, Mehling C, et al. (1999) Effect of wheat bran on serum lipids: influence of particle size and wheat protein. $J \mathrm{Am} \mathrm{Coll}$ Nutr 18: 159-165.

16. Andersson AAM, Andersson R, Piironen V, Lampi AM, Nystrom L, et al. (2013) Contents of dietary fibre components and their relation to associated bioactive components in whole grain wheat samples from the HEALTHGRAIN diversity screen. Food Chemistry 136: 1243-1248.

Copyright: (C2019 Mughal MH. This is an open-access article distributed under the terms of the Creative Commons Attribution License, which permits unrestricted use, distribution, and reproduction in any medium, provided the original author and source are credited. 